\title{
Identifying the Factors Influencing Users' Adoption of Social Networking Websites-A Study on Facebook
}

\author{
Neelotpaul Banerjee ${ }^{1} \&$ Arit Kumar Dey ${ }^{1}$ \\ ${ }^{1}$ Department of Management Studies, National Institute of Technology, Durgapur, India \\ Correspondence: Neelotpaul Banerjee, Department of Management Studies, National Institute of Technology, \\ Durgapur, India. E-mail: neelotpaul@gmail.com
}

\author{
Received: July 13, $2013 \quad$ Accepted: August 2, $2013 \quad$ Online Published: November 7, 2013 \\ doi:10.5539/ijms.v5n6p109 URL: http://dx.doi.org/10.5539/ijms.v5n6p109
}

\begin{abstract}
Success of a social networking websites (SNSs) primarily depends on the speed of consumer adoption of these websites. In this context, this study aims to examine empirically the factors that influence the adoption of Facebook by internet users. Facebook is chosen for this study as it is the most popular online social networking site. A survey involving 214 respondents is conducted. This study applied the statistical technique of exploratory factor analysis and extracted three major factors. Confirmatory factor analysis is used to confirm the exploratory factor model by determining the goodness of fit between hypothesized model and sample data.
\end{abstract}

Keywords: adoption, confirmatory factor analysis, Facebook, social networking sites

\section{Introduction}

Since their introduction, social media had been embraced rapidly by people across the globe in terms of adoption and usage levels, creating altogether a new platform for people to communicate with each other. Social networking sites (SNSs) provide a public forum that enables the exchange of digital information, and hyperlinks between users with common interests (Sledgianowski \& Kulviwat, 2009). These sites allow users to create profiles on the site, to post information and communicate with other users of the site (Kaplan \& Haenlein, 2010). Boyd and Ellison (2007) defined SNSs as web based services that allow individual users to construct a public or semi-public profile within a bounded system, and articulate a list of other users with whom they share a connection. These sites have changed the way people communicate with each other, share common interests, connect with friends, participate in discussion forums, and express themselves through a personalized blog or mini home page (Kim, Choi, Yan, \& Dooley, 2011). Online SNSs are digital networks in which users feel an intrinsic connection to other members (Wellman \& Gulia, 1999). Lee (2010) stated that social media has become vastly popular for "normal people" because it allows anyone to interact with content or deliver it. On the internet, SNSs are among the fastest growing segment.

Although the number of users of SNSs is huge, still the reason behind their rapid adoption is not very evident (Hart, Ridley, Taher, Sas, \& Dix, 2008). The objective of this study is to identify the factors that influence internet users' adoption of Facebook. The authors believe that Facebook is appropriate for this study due to its global spread and also it is the most popular SNS in India. Facebook was released worldwide in September 2006, and has become the most used SNS on the planet (Capua, 2012). An expanding user count in India and Brazil helped Facebook to increase its monthly active users (MAUs) to a whopping 1.11 billion in the first quarter of 2013(The Times of India, May 06, 2013). MAU's in India doubled to 78 million in Q1 2013 compared to Q1 2012.

In India, the largest age group using Facebook is currently 18-24, and is graduates who are looking for a job or planning further studies, followed by the users in the age group of 25-34 (Shah, 2011). As per the website www.simplify $360 . \mathrm{com}$, there are $73 \%$ male Facebook users and $27 \%$ users are female. The male to female ratio in terms of social media usage is 60:40 indicating that males use social media more than females.

\section{Literature Review}

There has been a growing body of literature on SNSs. Research studies in the past have focused on how social media can influence consumer purchase decision. Modern consumers seek peer advice over social networks and thus social media has promoted consumer-to-consumer communication and has made it possible for consumers 
and brands to interact with each other (Mangold \& Faulds, 2009). Fauser, Wiedenhofer, and Lorenz (2011) concluded that social media can be effective in influencing consumers during all stages of the consumer's purchase decision process. Cuming (2008) stated that overall online information played an influential role in the consumer's final purchase decision. Lo (2010) suggested that marketers can identify and categorize their target consumers on SNSs which allows marketers to post advertisements and links to those users.

A number of research works have studied Facebook in the context of motivation to use (Shi et.al. 2010; Gangadharbatla, 2008; Kwon \& Wen, 2010), usage effects (Andon, 2007), and concerns of identity (Dwyer, et. al. 2007). Facebook plays an important role in the process of forming and managing social capital by improving self esteem and low life satisfaction (Ellison, Steinfield, \& Lampe, 2007). Usage of social networks may include feelings of affiliation and belonging, goal achievement, values, and notions of accepted behavior (Ridings \& Gefen, 2004). Group affiliations influence members' opinions and positions on specific issues, and the interpersonal ties that the community members share increases their willingness to commit to goals identified by the group (Walther, 1996). As a result, social bonding develops among community members due to mutual liking (McCall, 1970). Group norms in social networking communities have powerful and consistent influences on group members' attitudes and behaviors (Hogg \& Terry, 2000; Terry \& Hogg, 1996). Social media websites benefit people by offering stability, diversity, and possibility (Cărtărescu, 2010). Some research has looked at how Facebook facilitates in developing online relationship among its users. Facebook promotes relationship building between its users by enabling users to track others in their communities (Lampe, Ellison \& Steinfield, 2007). Raacke and Bonds-Raacke (2008) found that the vast majority of college students use Facebook for making new friends and locating old acquaintances.

It is evident that despite the practical significance, little academic research addresses the concerns to identify the factors that influence users' adoption of Facebook. As existing research offer little insight into this particular domain, so, this study aims to fill the knowledge gap by identifying the factors that influence users' adoption of Facebook.

\section{Research Methodology}

To conduct an empirical investigation, a survey is conducted, using a questionnaire. The measurement instrument contains 15 items measuring adoption antecedents. This study focused on investigating the most prominent set of adoption factors, of which, some are derived from the literature and others are introduced by the authors.

Prior research has revealed that internet users join SNSs for staying in touch with friends, and make new friends (Lenhart \& Madden 2007). Other reasons for people joining SNSs are a sense of belonging and companionship (Wellman \& Gulia, 1999). Strong reasons for joining SNS can result in rapid adoption among users. Based on this two variables, easy and quick communication with friends \& family through Facebook (Var 12), and able to connect and socialize with new persons through Facebook (Var 3), are included in the questionnaire. Since SNSs provide a platform to socialize with new persons so users should be given an option to control what information they want to share with others. This can enhance adoption rate among users. This is reflected in the questionnaire through the item, Facebook gives users the choice and control over what they want to share with others (Var 5). Ridings and Gefen (2004) stated that feelings of affiliation need for goal achievement and self identity are reasons for adoption of SNSs. Internet users join SNSs to addresses the need for self identity (Hogg, 1996).For this reason the item Facebook is a source of self affirmation (Var 13) has been introduced in the study. Members of SNSs are likely to exchange information about their purchases, especially those they have enjoyed or those where they felt they had been ripped off. SNSs can be a god medium for information dissemination through word of mouth. People use SNSs to exchange word-of-mouth information with other members (Mellins, 2008). So it can be observed that SNSs provide opportunities to express one's opinion freely about different aspects of life. Consequently two items, Facebook provides an opportunity to act as opinion leader to family, friends, and peers (Var 9), and Facebook can be used to express social and political views (Var 7) are included in the study. Usage and adoption of Web technologies, such as SNS, depends on the user's ability to successfully understand, navigate, and evaluate content (Daugherty, Eastin, \& Gangadharbatla, 2005). SNS websites should be easy to navigate and users should have a nice experience while navigating the website. In order to attract membership SNSs should be dynamic in nature by introducing interesting features in the websites which the users can easily adopt. So, the authors have included one item, Facebook makes continuous improvements in its website features that the users enjoy and easily adopt (Var 1). Belanger, Hiller and Smith (2002) stated that privacy and security are critical for gaining customer's confidence in a website. Srininavasan (2004) concluded from his study that customers' security concern should be addressed for conducting e-business in a successful manner. The same should also be true for SNSs. Users need to provide a good amount of personal information for getting 
membership in different SNSs. SNSs managers have to ensure that this information remains secured to build confidence among the members. Past research has found trust to be strongly related to information disclosure (Metzger, 2004). Trust is also a core component of social exchange theory (Roloff, 1981). This aspect of SNS website feature has been included in the study through the items, Facebook provides multiple ways to protect one's account (Var 10), Facebook ensures protection of users' personal information from unauthorized access (Var 14), and users' privacy is protected in Facebook (Var 15). The remaining items in the construct are introduced by the authors based on their experiences. The authors based on their experiences of using SNS, and intuition feel that the items, interesting Apps on Facebook (Var 6), Facebook enable users 'check in' using their smart phones (Var 8), Facebook provides a platform for job networking (Var 2), web content of Facebook is visually appealing (Var 11), and advertisements on Facebook are not disturbing/interfering (Var 4), play decisive roles in influencing users to adopt SNSs.

A pilot study was conducted among a convenience sample of 12 persons to fine tune the questionnaire. Next the survey was conducted to collect the data. Data analysis was done using SPSS 16, and AMOS 21 was used to conduct the confirmatory factor analysis.

The samples consisted of internet users living in households in one major city in India. The respondents were randomly picked from those who are 18 years of age and above, of both sexes, either earning or with access to expendable income, and have Facebook membership for at least six months.

In this study Kish method of random sampling is done. The Kish method (Kish, 1965) involves some sequential step in which, a) the interviewer is to record the name, gender, age of all eligible persons and their relation to housewife (because she is the one who is mostly available), b) then the candidates are arranged according to their increasing age, and c) using a random table the respondent is chosen. In this study a total of 214 respondents completed the questionnaire. No replacement was made for households which refused to be a part of the survey or where the selected family member did not match the defined population.

\section{Results \& Discussion}

The demographic data of the samples are given in Table 1, and data related to Facebook usage are given in Table 2.

Table 1. Demographic data

\begin{tabular}{lll}
\hline GENDER & Frequency & Percent \\
Male & 135 & 63.1 \\
Female & 79 & 36.9 \\
Total & 214 & \\
\hline AGE (in years) & & \\
\hline & Frequency & Percent \\
18-20 & 39 & 18.2 \\
$21-30$ & 80 & 37.3 \\
$31-40$ & 63 & 29.4 \\
$41-50$ & 11 & 5.1 \\
$51-60$ & 14 & 6.5 \\
Above 60 & 7 & 3.5 \\
Total & 214 & \\
\hline EDUCATION & & \\
\hline & Frequency & Percent \\
Higher Secondary & 14 & 6.5 \\
Graduate & 86 & 40.2 \\
Post Graduate & 73 & 34.1 \\
Others & 41 & 19.2 \\
Total & 214 & \\
\hline MONTHLY INCOME (In Indian Rupees) & & \\
\hline & Frequency & Percent \\
Less than 10000 & 20 & 9.3 \\
10001-20000 & 22 & 10.3 \\
\hline & & \\
& & \\
\hline
\end{tabular}




\begin{tabular}{lll}
\hline 20001-30000 & 79 & 36.9 \\
$30001-40000$ & 47 & 22.0 \\
$40001-50000$ & 25 & 11.7 \\
Above 50000 & 21 & 9.8 \\
Total & 214 & \\
\hline PROFESSION & & \\
\hline & Frequency & Percent \\
Self employed & 10 & 4.7 \\
Service & 81 & 37.9 \\
Housewife & 14 & 6.5 \\
Student & 102 & 47.6 \\
Retired & 7 & 3.3 \\
Total & 214 & \\
\hline
\end{tabular}

Table 2. Facebook usage data

\begin{tabular}{lll}
\hline FACEBOOK MEMBERSHIP & & \\
\hline & Frequency & Percent \\
More than 6 months but less than 1 year & 14 & 6.5 \\
1 year-2 years & 21 & 9.8 \\
More than 2 years & 179 & 83.7 \\
Total & 214 & \\
\hline TIME SPENT ON FACEBOOK PER DAY & & Percent \\
& Frequency & 37.8 \\
Less than 30 minutes & 81 & 56.1 \\
30 minutes-1 hour & 120 & 6.1 \\
More than 1hour & 13 & \\
Total & 214 & \\
\hline
\end{tabular}

\subsection{Reliability Analysis}

The reliability analysis is performed for the entire scale containing the 15 variables using Cronbach's Alpha. A reliable scale can produce consistent results when it is used by the same individual more than once or when it is used by a group of people who have the same attitude toward a certain concept (Rodeghier, 1996).

A scale can be considered acceptable if the value of the Cronbach's Alpha is 0.7 or greater (George \& Mallery, 2003). The Cronbach's alpha for the 15 items measuring adoption antecedents is 0.894 , which indicates a high level of internal consistency for the scale to measure the underlying concept with this specific sample.

\subsection{Factor Analysis}

In this study, the authors have used factor analysis to reduce the 15 items measuring adoption antecedents. Factor analysis is used in data reduction to identify a small number of factors that explain most of the variance observed in a much larger number of manifest variables.

To test the sampling adequacy, Kaiser-Meyer-Olkin Measure of Sampling Adequacy is computed.

Table 3. KMO and Bartlett's test

\begin{tabular}{lll}
\hline \multicolumn{1}{l}{ Kaiser-Meyer-Olkin Measure of Sampling Adequacy. } & .851 \\
& Approx. Chi-Square & 2002.616 \\
Bartlett's Test of Sphericity & $\mathrm{df}$ & 105 \\
& Sig. & .000 \\
\hline
\end{tabular}

Kaiser (1974) recommends values greater than 0.5 as acceptable. As given in Table 3, Kaiser-Meyer-Olkin Measure of Sampling Adequacy is 0.851. This indicates that the factor analysis is appropriate for this data.

Bartlett's measure tests the null hypothesis that the original correlation matrix is an identity matrix. A significant test tells us that the R-matrix is not an identity matrix; therefore, there are some relationships between the 
variables that are to be included in the analysis. For this study, Bartlett's test is highly significant $(\mathrm{p}<0.001)$, and therefore factor analysis is appropriate.

Communalities are designed to show the proportion of variance that the factors contribute to explaining a particular variable.

Table 4. Communalities

\begin{tabular}{lcc}
\hline & Initial & Extraction \\
\hline Facebook makes continuous improvements in its website features that the users enjoy and can easily adopt (Var 1) & 1.000 & .803 \\
Facebook provides a platform for job networking (Var 2) & 1.000 & .550 \\
Able to connect and socialize with new persons through Facebook (Var 3) & 1.000 & .657 \\
Advertisements on Facebook are not disturbing/interfering(Var 4) & 1.000 & .642 \\
Facebook gives users the choice and control over what they want to share with others (Var 5) & 1.000 & .642 \\
Interesting Apps on Facebook (var 6) & 1.000 & .490 \\
Facebook can be used to express social \& political views (Var 7) & 1.000 & .655 \\
Facebook enable users 'check in' using their smart phones (Var 8) & 1.000 & .689 \\
Facebook provides an opportunity to act as opinion leader to family, friends, and peers (Var 9) & 1.000 & .643 \\
Facebook provides multiple ways to protect one's account (Var 10) & 1.000 & .698 \\
Web content of Facebook is visually appealing (Var 11) & 1.000 & .565 \\
Easy and quick communication with friends \& family through Facebook (Var 12) & 1.000 & .770 \\
Facebook is a source of self affirmation (Var 13) & 1.000 & .655 \\
Facebook ensures protection of users' personal information from unauthorized access (Var 14) & 1.000 & .784 \\
Users' privacy is protected in Facebook (Var 15) & 1.000 & .668
\end{tabular}

Extraction Method: Principal Component Analysis.

The above table shows communalities before and after extraction. The communalities in the column labelled Extraction reflect the common variance in the data structure. So, $80.3 \%$ of the variance associated with question 1 is common or shared variance. After extraction some of the factors are discarded and so some information is lost. The amount of variance in each variable that can be explained by the retained factors is represented by the communalities after extraction.

Principal Component Analysis works on the initial assumption that all variance is common, therefore, before extraction the communalities are all 1 . The amount of variance in each variable that can be explained by the retained factors is represented by the communalities, as shown in Table 5, after extraction.

Table 5. Total variance explained

\begin{tabular}{|c|c|c|c|c|c|c|c|c|c|}
\hline \multirow[t]{2}{*}{ Component } & \multicolumn{3}{|c|}{ Initial Eigenvalues } & \multicolumn{3}{|c|}{ Extraction Sums of Squared Loadings } & \multicolumn{3}{|c|}{ Rotation Sums of Squared Loadings } \\
\hline & Total & $\begin{array}{l}\% \text { of } \\
\text { Variance }\end{array}$ & Cumulative \% & Total & $\begin{array}{l}\% \text { of } \\
\text { Variance }\end{array}$ & Cumulative \% & Total & $\begin{array}{l}\% \text { of } \\
\text { Variance }\end{array}$ & Cumulative $\%$ \\
\hline$\overline{\operatorname{Var} 1}$ & 6.939 & 46.262 & 46.262 & 6.939 & 46.262 & 46.262 & 4.936 & 32.908 & 32.908 \\
\hline $\operatorname{Var} 2$ & 1.706 & 11.375 & 57.638 & 1.706 & 11.375 & 57.638 & 2.695 & 17.963 & 50.871 \\
\hline $\operatorname{Var} 3$ & 1.264 & 8.429 & 66.066 & 1.264 & 8.429 & 66.066 & 2.279 & 15.195 & 66.066 \\
\hline $\operatorname{Var} 4$ & .838 & 5.587 & 71.653 & & & & & & \\
\hline $\operatorname{Var} 5$ & .748 & 4.986 & 76.639 & & & & & & \\
\hline $\operatorname{Var} 6$ & .645 & 4.299 & 80.938 & & & & & & \\
\hline $\operatorname{Var} 7$ & .539 & 3.593 & 84.531 & & & & & & \\
\hline $\operatorname{Var} 8$ & .506 & 3.375 & 87.906 & & & & & & \\
\hline Var 9 & .407 & 2.716 & 90.622 & & & & & & \\
\hline Var 10 & .355 & 2.367 & 92.988 & & & & & & \\
\hline Var 11 & .314 & 2.094 & 95.083 & & & & & & \\
\hline Var 12 & .275 & 1.832 & 96.915 & & & & & & \\
\hline Var 13 & .219 & 1.462 & 98.377 & & & & & & \\
\hline Var 14 & .150 & 1.001 & 99.377 & & & & & & \\
\hline Var 15 & .093 & .623 & 100.000 & & & & & & \\
\hline
\end{tabular}

Extraction Method: Principal Component Analysis. 
Table 5, lists the Eigen values which are designed to show the proportion of variance accounted for by each factor (George and Mallery, 2010). Before extraction there are fifteen components in the data set. The Eigen values associated with each component represent the variance explained by that particular component. Next all components with Eigen value greater than 1 are extracted, which leaves us with three factors.

The percentage of total variance is used as an index to determine how well the total factor solution accounts for what the variables together represent. The index for the present study accounts for $66.066 \%$ of the total variance for adoption of Facebook. This is a good extraction as it can economize on a number of factors (from fifteen, it has reduced to three factors), while we have lost only $33.934 \%$ information content.

Table 6, shows the Rotated Component Matrix which is a matrix of factor loadings for each variable onto each factor. Comrey (1973) suggested that loadings of 0.55 are good, those of 0.63 very good, and those of 0.71 are excellent, with increased loading becoming more vital in determining the factor. Factor loadings less than 0.5 have not been displayed as the criterion value has been selected as 0.5 .

Table 6. Rotated component matrixa

\begin{tabular}{|c|c|c|c|}
\hline & Component & & \\
\hline & 1 & 2 & 3 \\
\hline \multicolumn{4}{|l|}{ RICH IN USEFULNESS } \\
\hline $\begin{array}{l}\text { Easy and quick communication with friends } \\
\& \text { family through Facebook (Var 12) }\end{array}$ & 833 & & \\
\hline $\begin{array}{l}\text { Able to connect and socialize with new } \\
\text { persons through Facebook (Var 3) }\end{array}$ & .792 & & \\
\hline $\begin{array}{l}\text { Facebook is a source of self affirmation } \\
\text { (Var 13) }\end{array}$ & .762 & & \\
\hline $\begin{array}{l}\text { Facebook provides an opportunity to act as } \\
\text { opinion leader to family, friends, and peers } \\
\text { (Var 9) }\end{array}$ & .737 & & \\
\hline $\begin{array}{l}\text { Facebook can be used to express social and } \\
\text { political views (Var 7) }\end{array}$ & .723 & & \\
\hline Interesting Apps on Facebook (Var 6) & .665 & & \\
\hline $\begin{array}{l}\text { Facebook enable users 'check in' using } \\
\text { their smartphones (Var 8) }\end{array}$ & .655 & & \\
\hline $\begin{array}{l}\text { Facebook provides a platform for job } \\
\text { networking (Var 2) }\end{array}$ & .653 & & \\
\hline \multicolumn{4}{|l|}{$\begin{array}{l}\text { WEB SITE DESIGNED TO ENHANCE } \\
\text { USER'S CONVENIENCE }\end{array}$} \\
\hline $\begin{array}{l}\text { Facebook makes continuous improvements } \\
\text { in its website features that the users enjoy } \\
\text { and easily adopt (Var } 1 \text { ) }\end{array}$ & & .798 & \\
\hline $\begin{array}{l}\text { Facebook gives users the choice and control } \\
\text { over what they want to share with others } \\
\text { (Var 5) }\end{array}$ & & .745 & \\
\hline $\begin{array}{l}\text { Web content of Facebook is visually } \\
\text { appealing (Var 11) }\end{array}$ & & .658 & \\
\hline $\begin{array}{l}\text { Advertisements on Facebook are not } \\
\text { disturbing/interfering (Var 4) }\end{array}$ & & .610 & \\
\hline \multicolumn{4}{|l|}{ TRUSTWORTHY } \\
\hline $\begin{array}{l}\text { Facebook provides multiple ways to protect } \\
\text { one's account (Var 10) }\end{array}$ & & & .851 \\
\hline $\begin{array}{l}\text { Facebook ensures protection of users' } \\
\text { personal information from unauthorized } \\
\text { access (Var } 14 \text { ) }\end{array}$ & & & .735 \\
\hline $\begin{array}{l}\text { Users' privacy is protected in Facebook } \\
\text { (Var 15) }\end{array}$ & & & .714 \\
\hline
\end{tabular}

Extraction Method: Principal Component Analysis.

Rotation Method: Varimax with Kaiser Normalization. 
The three factors, for adoption of Facebook, obtained through factor analysis are named as, Rich in usefulness, Web site design enhance user's convenience, and Trustworthy.

\subsection{Exploratory Factor Analysis}

Exploratory factor analysis revealed 3 factors with 15 items. After that Confirmatory factor analysis (CFA) has been conducted by using AMOS 21. CFA is used to confirm the exploratory factor model by determining the goodness of fit between hypothesized model and sample data.

Table 7. CMIN

\begin{tabular}{llllll}
\hline Model & NPAR & CMIN & DF & P & CMIN/DF \\
\hline Default model & 60 & 64.018 & 60 & .337 & 1.067 \\
Saturated model & 120 & .000 & 0 & & \\
Independence model & 15 & 2059.005 & 105 & .000 & 19.610 \\
\hline
\end{tabular}

From the first set of fit statistics, CMIN (minimum discrepancy), it is observed that the chi-square value is 64.018 at 60 degrees of freedom. The corresponding $\mathrm{p}$ value is 0.337 . The CMIN/DF (normed chi-square) shows a value of 1.067, which is well within the acceptable level of 1.0 to 2.0.So all fit statistics, are adequate for the acceptance of the model.

Table 8. RMR, GFI

\begin{tabular}{lcccc}
\hline Model & RMR & GFI & AGFI & PGFI \\
\hline Default model & .023 & .961 & .922 & .480 \\
Saturated model & .000 & 1.000 & & \\
Independence model & .295 & .271 & .166 & .237 \\
\hline
\end{tabular}

RMR (Root mean square residual) are best interpreted in the metric of the correlation matrix. The standardized RMR, then, represents the average value across all standardized residuals. In a well fitting model, this value shall be 0.05 or less. The RMR value is .023 which is within the acceptable for the goodness of model fit.

For both GFI (Goodness of fit index) and AGFI (Adjusted goodness of fit index) indices values close to 1.00 are indicative of good fit. Based on the GFI and AGFI values of .961 \& .922 respectively, it can be concluded that the hypothesized model fits the sample data quiet well.

Typically, parsimony based indices having lower values than the threshold level are generally perceived as acceptable for other normed indices of fit. In this study a PGFI (Parsimony goodness of fit index) value of .480 accompanied by goodness-of-fit indices in the .90 s can be considered to be consistent.

Table 9. Baseline comparisons

\begin{tabular}{llllll}
\hline Model & NFI & RFI & IFI & TLI & CFI \\
& Delta1 & rho1 & Delta2 & rho2 & \\
\hline Default model & .969 & .946 & .998 & .996 & .998 \\
Saturated model & 1.000 & & 1.000 & & 1.000 \\
Independence model & .000 & .000 & .000 & .000 & .000 \\
\hline
\end{tabular}

A value close to .95 for both the NFI (Normal fit index) and CFI (Comparative fit index) is considered representative of a well fitting model (Hu \& Bentler, 1999). The NFI and CFI values are .969 and .998 respectively which indicates that the model fitted the data well in the sense that the hypothesized model adequately describe the sample data. The RFI (Relative fit index) coefficient values close to .95 indicate superior fit (Hu \& Bentler, 1999). The RFI value is .946 indicating good fit. The value of IFI (Incremental index of fit) is .998 which is consistent with that of CFI in reflecting a well fitting model. Finally, the TLI (Tucker-Lewis index), consistent with the other indices noted here, with values close to .95 indicate good fit. It is observed that TLI is .996 which is acceptable. 
Table 10. Parsimony-adjusted measures

\begin{tabular}{llll}
\hline Model & PRATIO & PNFI & PCFI \\
\hline Default model & .571 & .554 & .570 \\
Saturated model & .000 & .000 & .000 \\
Independence model & 1.000 & .000 & .000 \\
\hline
\end{tabular}

The above cluster of fit indices relates to the issue of model parsimony. The first fit index PRATIO (Parsimony ratio) is computed relative to the NFI and CFI. A PNFI and PCFI of .571 and .554 respectively fall in the range of expected values.

Table 11. NCP

\begin{tabular}{llll}
\hline Model & NCP & LO 90 & HI 90 \\
\hline Default model & 4.018 & .000 & 27.470 \\
Saturated model & .000 & .000 & .000 \\
Independence model & 1954.005 & 1810.282 & 2105.098 \\
\hline
\end{tabular}

The next set of fit statistics provides the NCP (Non centrality parameter) estimate. From the above table, it is observed that the hypothesized model yielded a non centrality parameter of 4.018 . The confidence interval indicates that we can be $90 \%$ confident that the population value of the non centrality parameter lies between 0.00 and 27.470 .

Table 12. FMIN

\begin{tabular}{lllll}
\hline Model & FMIN & F0 & LO 90 & HI 90 \\
\hline Default model & .301 & .019 & .000 & .129 \\
Saturated model & .000 & .000 & .000 & .000 \\
Independence model & 9.667 & 9.174 & 8.499 & 9.883 \\
\hline
\end{tabular}

The hypothesized model is not acceptable if the value of FMIN (Minimum discrepancy function) is substantially away from zero. In this study, the FMIN value is .301, which is not substantially away from zero resulting in the acceptance of the model.

Table 13. RMSEA

\begin{tabular}{lllll}
\hline Model & RMSEA & LO 90 & HI 90 & PCLOSE \\
\hline Default model & .018 & .000 & .046 & .973 \\
Independence model & .296 & .285 & .307 & .000 \\
\hline
\end{tabular}

RMSEA (Root mean square error of approximation) value less than .05 indicate good fit and values as high as .08 represent reasonable errors of approximation in the population. For the use of confidence intervals to assess the precision of RMSEA estimates, AMOS reports a 90\% interval around the RMSEA value. In addition to reporting a confidence interval around the RMSEA value, AMOS tests for the closeness of fit (PCLOSE). That is, it tests the hypothesis that the RMSEA is good in the population. The p-value for this test should be more than 0.5 (Joreskog \& Sorbom, 1996). It is observed that RMSEA value for model is .018, with $90 \%$ confidence interval ranging from .000 to .046 and the p-value for the test of closeness of fit equal to .973 . So it can be concluded that the hypothesized model fits the data well.

Table 14. AIC

\begin{tabular}{lllll}
\hline Model & AIC & BCC & BIC & CAIC \\
\hline Default model & 184.018 & 193.764 & 385.976 & 445.976 \\
Saturated model & 240.000 & 259.492 & 643.917 & 763.917 \\
Independence model & 2089.005 & 2091.441 & 2139.494 & 2154.494 \\
\hline
\end{tabular}


The AIC (Akaike's information criterion), and CAIC (Consistent version of the AIC) are used in the comparison of two or more models, with smaller values representing a better fit of the model (Hu \& Bentler, 1995). The BCC (Browne-Cudeck criterion) and the BIC (Bayes information criterion) operate in the same manner as the AIC and CAIC. The basic difference among these indices is that both the BCC and BIC impose greater penalties than either the AIC or CAIC for model complexity. In this study all the four fit indices for the hypothesized model are substantially smaller than they are for either independence or the saturated model.

Table 15. ECVI

\begin{tabular}{lllll}
\hline Model & ECVI & LO 90 & HI 90 & MECVI \\
\hline Default model & .864 & .845 & .974 & .910 \\
Saturated model & 1.127 & 1.127 & 1.127 & 1.218 \\
Independence model & 9.808 & 9.133 & 10.517 & 9.819 \\
\hline
\end{tabular}

Application of the ECVI (Expected cross validation index) model assumes a comparison of models whereby an ECVI index is computed for each model, and then all ECVI values are placed in rank order; the model having the smallest ECVI value exhibits the greatest potential for replication. Given the lower ECVI value for the hypothesized model, compared with both the independence and saturated models, it can be concluded that it represents the best fit to the data. Again it can be seen that the confidence interval ranges from .773 to 1.034.These results suggest that the hypothesized model is well fitting and represents a reasonable approximation to the population. The last fit statistic MECVI (modified ECVI), is actually identical to the BCC, except for a scale factor

Table 16. HOELTER

\begin{tabular}{lll}
\hline \multirow{2}{*}{ Model } & HOELTER & HOELTER \\
& .05 & .01 \\
\hline Default model & 264 & 295 \\
Independence model & 14 & 15 \\
\hline
\end{tabular}

Hoelter (1983) proposed that a value in excess of 200 is indicative of a model that adequately represents the sample data. Both the 0.5 and $.01 \mathrm{CN}$ values for the hypothesized model are greater than 200 (264 and 295 respectively). Interpretation of this finding, indicates that the size of the sample $(\mathrm{N}=214)$ was satisfactory according to Hoelter's benchmark.

According to the different indices of goodness-of-fit statistics, as per the present study, the hypothesized model passes all the goodness-of-fit statistics. It indicates that the sample data fit the model well in terms of absolute fit measures like CMIN, FMIN, RMR, RMSEA and ECVI; parsimonious fit measures like PGFI, PNFI, and AIC; and incremental fit measures like TLI, NFI, AGFI and CFI.

\section{Conclusion}

In this study, the authors first identified 15 key variables for adoption of Facebook and reduced them to 3 factors through exploratory and confirmatory factor analysis.

The first factor is Rich in usefulness. Facebook provides a great way to keep in contact with friends, families, and explore new friends. Facebook gives freedom to an individual to express oneself like never before, and facilitates the development of social bond with unknown persons removing geographical and cultural barriers that were unthinkable in the past. Facebook can be considered as a source of self affirmation. Facebook is instrumental in giving users a sense of well being by restoring user's perception about oneself as a person liked and adored by a network of friends, peers and family. Users can get leads for new jobs and enjoy interesting applications on Facebook. Facebook can be considered as one's home on the internet which creates an online social identity for the person. It can be concluded that these multi facet benefits influences users to adopt and integrate Facebook as a part of their daily lives.

The second factor for adoption of Facebook is Web site design enhance users' convenience. Web design is the creation of web sites focusing on the aesthetics and the mechanics of a website's operation. Convenience is anything that simplifies work, adds to one's ease or comfort. Facebook is a visually appealing web site that gives 
users the control over what they want to share with others. The website has user friendly aspects of interactivity, which enhances its functionality. Unlike a vast majority of web sites, the advertisements on Facebook don't annoy users. Advertisements don't appear as banners in the center, top or left sidebar of Facebook pages. As a result the users can navigate through the web pages of Facebook without getting disturbed. Users feel comfortable to use Facebook which in turn has a big impact on users' intention to adopt Facebook.

Trustworthy is the third factor for Facebook adoption. Activities performed by the users in Facebook include sharing personal information, photos and videos, connecting with unknown persons, which raises privacy and information security concerns. So trust becomes an important issue in the adoption of Facebook. Users tend to choose a social networking site that represents a set of attributes that can be trusted. Users perceive Facebook to be trustworthy as they belief that Facebook take utmost care to protect the privacy of users and prevent unauthorized access to users' sensitive personal information. Facebook provides multiple security options like remote logout, one-time passwords, apps password, active sessions, login approvals, login notifications, secure browsing, trusted contacts, and social authentication. These sophisticated security features repose users' faith on Facebook. The perceived trust users have on Facebook's honesty and integrity plays a critical role in the adoption of Facebook.

\section{Managerial Implications}

As social network platforms have evolved over the years, of increasing importance is content that differentiates SNSs. SNSs should demonstrate the creativity to design of niche content to pull membership. The factors influencing the adoption of SNSs suggest that SNSs managers should devise strategies to take into consideration these factors while designing the websites. Incorporating these factors in the form of website features can have a positive influence on the users and increase their confidence level on the SNSs. Website features namely rich in usefulness, and adding convenience to the users can elicit positive attitudes among the users and influence users to adopt those SNSs. SNS owners should gain trust of users by ensuring them their privacy is protected and information is secured by implementing multiple complex security system. SNSs should reflect artistic sensibility without compromising with functionality aspects.SNS owners should try to appeal to the internet users through these features to increase membership and participation. More traffic to SNSs in turn will also bring in more advertisements to the websites and consequently more revenue for the SNSs owners. Increased membership shall provide opportunities to SNS managers to attract savvy businesses that can link and promote their goods and services through SNSs. This may result in users looking at their chosen SNS as a one stop place for all their digital and entertainment needs. A deeper understanding of the factors shall allow the SNSs managers to incorporate them in the website and monitor them more effectively.

\section{Limitations}

Because it is exploratory in nature, the present study also has some limitations. This study deals with only one SNS i,e Facebook. There are a number of other SNSs available on the internet which is not included in this study. So, future work can include a number of popular SNSs to understand the factors influencing adoption of SNSs more vividly. Secondly, this study has been done in Indian context only. Further research should be done across different countries and comparisons can be made. Consequently, the findings of this study should be further tested with a larger sample of internet users having membership in different SNSs. Additional research work should identify other variables influencing the adoption of SNSs.

\section{References}

Andon, S. P. (2007). Evaluating computer mediated communication on the university campus: The impact of Facebook.com on the development of romantic relationships, in college of communication. Master Thesis, The Florida State University, Florida, USA.

Arbuckle, J. L. (2007). Amos 16.0 User's Guide. Chicago: SPSS.

Belanger, F., Hiller, J. S., \& Smith, W. J. (2002). Trustworthiness in electronic commerce: The role of privacy, security, and site attributes. Journal of Strategic Information Systems, 11(December), 245-270. http://dx.doi.org/10.1016/S0963-8687(02)00018-5.

Boyd, D. M., \& Ellison, N. B. (2007). Social Network Sites: Definition, History, and Scholarship. Journal of Computer-Mediated Communication, 13(1). http://dx.doi.org/10.1111/j.1083-6101.2007.00393.x

Capua, I. D. (2012). A literature review of research on Facebook use. The Open Communication Journal, 6 , 37-42. http://dx.doi.org/10.2174/1874916X01206010037 
Cărtărescu, I. (2010). Utility of online communities-ways one can benefit from one's online life. Journal of Comparative Research in Anthropology \& Sociology, 1(2), 79-91.

Comrey, A. (1973). A First Course on Factor Analysis. London: Academic Press.

Cuming, L. (2008). Engaging Consumers Online: The Impact of Social Media on Purchasing Behaviour. DEI Worldwide. $\quad$ Retrieved April 6, 2011, from http://www.deiworldwide.com/files/DEIStudyEngaging\%20ConsumersOnlineSummary.pdf

Daugherty, T., Eastin, M., \& Gangadharbatla, H. (2005). e-CRM: Understanding Internet Confidence and Implications for Customer Relationship Management. In Irvine Clark III \& Theresa Flaherty (Eds.), Advances in Electronic Marketing (pp. 67-82). Harrisonburg, VA: James Madison University, Idea Group Publishing, Inc.

Digital Marketing in India. (2013). Retrieved July 24, 2013, from http://simplify360.com/blog/digital-marketing-in-india-2013/

Dwyer, C., Hiltz, S. R., \& Passerini, K. (2007). Trust and privacy concern within social networking sites: A comparison of Facebook \& MySpace. Proceedings of the 13th Americas Conference on Information Systems, Keystone, Colorado.

Ellison, N., Steinfield, C., \& Lampe, C. (2007). The benefits of Facebook "friends": Social capital and college students' use of online social network sites. Journal of Computer Mediated Communication, 12(4), 1143-1168. http://dx.doi.org/10.1111/j.1083-6101.2007.00367.x

Facebook India Active Users Up 50\% to 78M in Q1-2013. (2013). Retrieved June 4, 2013, from $\mathrm{http}: / / \mathrm{www} . m e d i a n a m a . c o m / 2013 / 05 / 223$-facebook-india-78-million-users

Facebook India user base up $50 \%$ in Q1. (2013). Retrieved June 12, 2013, from http://articles.timesofindia.indiatimes.com/2013-05-06/internet/39063530_1_registered-facebook-user-mont hly-active-users-mobile-maus

Fauser, S. G., Wiedenhofer, J., \& Lorenz, M. (2011). Touchpoint social web: an explorative study about using the social web for influencing high involvement purchase decisions. Problems and Perspectives in Management, 9(1), 39-45.

Gangadharbatla, H. (2008). Facebook me:collective self esteem, need to belong, and internet self efficacy as predictors of the igeneration's attitudes toward social networking sites. Journal of Interactibe Advertising, $8(2), 5-15$.

George, D., \& Mallery, P. (2003). SPSS for Windows step by step: A simple guide and reference. 11.0 update (4th ed.). Boston: Allyn \& Bacon.

George, D., \& Mallery, P. (2010). SPSS for Windows Step by Step: A Simple Guide and Reference, 18.0 Update. Pearson Education, Inc.

Hart, J., Ridley, C., Taher, F., Sas, C., \& Dix, A. (2008). Exploring the facebook experience: a new approach to usability. In NordiCHI '08 Proceedings of the 5th Nordic conference on Human-computer interaction: building bridges (pp. 471-474). New York: ACM Press.

Hoelter, J. W. (1983). Factorial Invariance and Self-Esteem: Reassessing Race and Sex Differences. Social Forces, 61(3), 835-846.

Hogg, M. A. (1996). Group structure and social identity. In W. P. Robinson (Ed.), Social groups and identities: Developing the legacy of Henri Taifel (pp. 65-94). UK: Butterworth-Heinemann.

Hogg, M. A., \& Deborah, J. T. (2000). Social Identity and Self-Categorization Processes in Organizational Contexts. Academy of Management Review, 25(1), 121-140.

Hu, L., \& Bentler, P. M. (1995). Evaluating model fit. In R. H. Hoyle (Ed.), Structural equation modelling: Concepts, issues, and applications (pp. 76-99). Thousand Oaks, CA: Sage.

Hu, L., \& Bentler, P. M. (1999). Cutoff criteria for fit indexes in covariance structure analysis: Coventional criteria versus new alternatives. Structural Equation Modeling, 6(1), 1-55. http://dx.doi.org/10.1080/10705519909540118

Jöreskog, K. G., \& Sörbom, D. (1996). LISREL 8 user's reference guide. Uppsala, Sweden: Scientific Software International. 
Kaiser, H. F. (1974). An index of factorial simplicity. Psychometrica, 39, 31-36. http://dx.doi.org/10.1007/BF02291575

Kaplan, A. M., \& Haenlein, M. (2010). Users of World, Unite! The Challenge and Opportunities of Social Media. Business Horizons, 53(1), 59-68. http://dx.doi.org/10.1016/j.bushor.2009.09.003

Kim, Y., Choi, T. Y., Yan, T., \& Dooley, K. (2011). Structural investigation of supply networks: A social network analysis approach. Journal of Operations Management, 29, 194-211. http://dx.doi.org/10.1016/j.jom.2010.11.001

Kish, L. (1965). Survey Sampling. New York, NY: John Wiley \& Sons, Inc.

Kwon, O., \& Wen, Y. (2010). An empirical study of the factors affecting social network service use. Computers in Human Behaviour, 26(2), 254-263. http://dx.doi.org/10.1016/j.chb.2009.04.011

Lampe, C., Ellison, N., \& Steinfield, C. A. (2007). Familiar Face (book): Profile Elements as Signals in an Online Social Network. San Jose, CA: ACM Press.

Lee, D. (2010). Growing popularity of social media and business strategy. SERI Quarterly, 3(4), 112-117.

Lenhart, A., \& Madden, M. (2007). Social Networking Websites and Teens: An Overview. Pew Internet \& American Life Project. Retrieved July 26, 2013, from http://www.pewinternet.org/PPF/r/198/report_display.asp

Lo, J. P. (2010). The effectiveness of WOM by using Facebook as an implementation in movie industry. State California University, Sacramento.

Mangold, W. G., \& Faulds, D. J. (2009). Social media: the new hybrid element of the promotion mix. Business Horizons, 52(4), 357-365. http://dx.doi.org/10.1016/j.bushor.2009.03.002

McCall, G. J. (1970). The Social Organization of Relationships. In G. J. McCall, M. M. McCall, N. K. Denzin, G. D. Suttles, \& S. B. Kurth (Eds.), Social Relationships (pp. 3-34). Chicago: Aldine Publishing Company.

Mellins, M. (2008). The female vampire community and online social networks: Virtual celebrity and mini communities: Initial thoughts. International Journal of Media \& Cultural Politics, 4(2), 254-258. http://dx.doi.org/10.1386/macp.4.2.254_3

Metzger, M. J. (2004). Privacy, Trust, and Disclosure: Exploring Barriers to Electronic Commerce. Journal of Computer-Mediated Communication, 4(9).

Raacke, J. D., \& Bonds-Raacke, J. M. (2008). MySpace \& Facebook: Applying the uses and gratifications theory to exploring friend networking sites. Cyber Psychology and Behavior, 11, 169-174. http://dx.doi.org/10.1089/cpb.2007.0056

Ridings, C., \& Gefen, D. (2004). Virtual Community Attraction: Why People Hang Out Online. Journal of $\begin{array}{llll}\text { Computer-Mediated } & \text { Communication, } & \text { Retrieved } & \text { from }\end{array}$ http://jcmc.indiana.edu/vol10/issue1/ridings_gefen.html

Rodeghier, M. (1996). Surveys with confidence: A practical guide to survey research using SPSS. Chicago: SPSS Inc.

Roloff, M. E. (1981). Interpersonal communication: The social exchange approach. Beverly Hills, CA: Sage Publications, Inc

Shah, S. (2011). Social Media in India: Statistics \& Insights. Retrieved July 24, 2013, from http://www.techinasia.com/social-media-india/

Shi, N., Lee, M. K. O., Cheung, C., \& Chen. H. (2010). The continuance of online social networks: How to keep people using Facebook? The $43^{\text {rd }}$ Hawai International Conference on System Sciences, Koloa, Kauai, Hawaii.

Sledgianowski, D., \& Kulviwat, S. (2009). Using Social Network Sites: The Effects of Playfulness, Critical Mass and Trust in an Hedonic Context. The Journal of Computer Information Systems, 48(4), 74-83.

Srinivasan, S. (2004). Role of trust in e-business success. Information Management \& Computer Security, 12(1), 66-72. http://dx.doi.org/10.1108/09685220410518838

Terry, D. J., \& Michael, A. H. (1996). Group Norms and the Attitude-Behavior Relationship: A Role for Group Identification. Personality and Social Psychology Bulletin, 22(8), 776-793. http://dx.doi.org/10.1177/0146167296228002 
Walther, J. B. (1996). Computer-Mediated Communication: Impersonal, Interpersonal, and Hyperpersonal Interaction. Communication Research, 23(1), 3-43. http://dx.doi.org/10.1177/009365096023001001

Wellman, B., \& Milena, G. (1999). Net-Surfers Don't Ride Alone: Virtual Communities as Communities. In B. Wellman (Ed.), Networks in the Global Village (pp. 331-366). Boulder, CO: Westview Press.

23 Interesting Social Media Statistics and Facts about India. (2013). Retrieved from http://simplify360.com/blog/23-interesting-social-media-statistics-and-facts-about-india/

\section{Copyrights}

Copyright for this article is retained by the author(s), with first publication rights granted to the journal.

This is an open-access article distributed under the terms and conditions of the Creative Commons Attribution license (http://creativecommons.org/licenses/by/3.0/). 